\title{
IN PRAISE OF TAX HAVENS: INTERNATIONAL TAX PLANNING AND FOREIGN DIRECT INVESTMENT
}

\author{
QING HONG \\ MICHAEL SMART
}

CESIFO WORKING PAPER NO. 1942

CATEGORY 1: PubliC FinANCE

MARCH 2007

An electronic version of the paper may be downloaded
- from the SSRN website: $\quad$ www.SSRN.com
- from the RePEc website: $\quad$ www.RePEc.org
- from the CESifo website: $\quad$ www.CESifo-group.de 


\title{
In PRAise OF TAX HAVENS: INTERNATIONAL TAX PLANNING AND FOREIGN DiRECT INVESTMENT
}

\begin{abstract}
The multinationalization of corporate investment in recent years has given rise to a number of international tax avoidance schemes that may be eroding tax revenues in industrialized countries, but which may also reduce tax burdens on mobile capital and so facilitate investment. Both the welfare effects of and the optimal response to international tax planning are therefore ambiguous. Evaluating these factors in a simple general equilibrium model, we find that citizens of high-tax countries benefit from (some) tax planning. Paradoxically, if tax rates are not too high, an increase in tax planning activity causes a rise in optimal corporate tax rates, and a decline in multinational investment. Thus fears of a "race to the bottom" in corporate tax rates may be misplaced.
\end{abstract}

JEL Code: H2, H7.

Keywords: income shifting, tax planning, foreign direct investment, tax competition, thin capitalization.

\author{
Qing Hong \\ Department of Economics \\ University of Toronto \\ 150 St. George St. \\ Toronto ON M5S $3 G 7$ \\ Canada
}

\author{
Michael Smart \\ Department of Economics \\ University of Toronto \\ 150 St. George St. \\ Toronto ON M5S 3G7 \\ Canada \\ msmart@economics.utoronto.ca
}

Revised Version

October 30, 2006

Thanks to Sam Bucovetsky and Jack Mintz for discussions and comments. 


\section{Introduction}

In recent years, the process of globalization has brought nations closer together and, apparently, increased the international mobility of corporate activity. Two aspects of globalization have had important and conceptually distinct implications: reductions in transportation and communication costs may make real business investment more mobile across jurisdictional boundaries, and financial innovation and liberalization may facilitate international tax avoidance by less footloose firms. In this paper, we argue that these two aspects of globalization can have very different implications for the welfare of citizens and for the appropriate policy response by governments.

Increased mobility of goods and services is apt to give rise to an erosion of corporate tax bases in high-tax industrialized countries, a decline in tax revenues and a rise in competition among governments. Countries seeking to attract and retain mobile investment and the associated tax revenues may be induced to reduce tax rates below the levels that would obtain in the absence of mobility. In the view of some commentators, indeed, increased mobility can lead to a "race to the bottom" driving business tax rates to minimal levels, due to the fiscal externalities that mobility creates. These arguments notwithstanding, there appears to be very little evidence of a general decline in effective tax rates on capital in recent years (Slemrod, 2004).

Financial mobility is manifested in the decisions of multinational enterprises to separate research and development and capital financing activities from production and sales of outputs, and so to engage in "tax planning" to realize income from intellectual property and from capital in jurisdictions different from those where real economic activities are located. The implications of financial mobility are more subtle: When firms may shift income to tax havens and other low-tax jurisdictions through financial transactions, real investment choices of firms and the tax policy environment of governments are changed. Tax planning tends to make the location of real investment less responsive to tax rate differentials, even as taxable income becomes more elastic. While tax planning may reduce revenues of hightax jurisdictions, therefore, it may have offsetting effects on real investment that are attractive to governments. In principle, then, the presence of international tax planning opportunities may allow countries to maintain or even increase high business tax rates, while preventing an outflow of foreign direct investment.

In this paper, we offer a simple model of these competing effects of in- 
ternational tax planning on the mobility of business tax bases and business investment. We argue that the investment-enhancing effects of international tax planning can dominate the revenue-erosion effects. The implications of this view are strong: an increase in international tax avoidance can lead to an increase in both statutory and effective tax rates on capital, if initial tax rates are not too high, and an increase in the welfare of citizens of high-tax countries.

Our results therefore offer a new perspective on the recent debate over legal responses to international tax planning in the US and elsewhere. Commenting on revelations of Microsoft's tax planning practices in Europe, a recent New York Times editorial asserted "outsourcing is extending itself [from manufacturing employment] to taxes, in large part because the United States Congress has given business the loopholes to do it." ${ }^{1}$ But, consistent with our model, governments may be reluctant to close such "loopholes," because of fears of losses in multinational employment and, in particular, expatriations of ownership and headquarters operations to low-tax countries. $^{2}$

Early empirical research is suggestive of the role of international tax planning on both revenues and investment. Hines and Rice (1994) find a negative relationship between tax rates of host countries and measures of the profitability of affiliates of US multinationals. Likewise, Mintz and Smart (2004) find evidence of greater tax base mobility among firms organized to take advantage of tax planning opportunities; however, the same firms exhibit greater mobility in the location of their assets as well. More recently, Desai et al. (2004b) have shown that US multinationals with an affiliate in a tax haven also invest more in neighboring non-haven countries, which is suggestive of the mitigating effect of tax planning on investment.

The starting point for an analysis of the effects of income shifting must be an understanding of the role of a source-based corporate income tax in a world of mobile capital. In the standard analysis, governments in small, open economies should eschew taxes on mobile factors like international capital, since they are distortionary and will ultimately be borne by immobile domestic factors anyway (Gordon, 1986; Bucovetsky and Wilson, 1991). In our perspective, governments may nevertheless rely on corporate income taxes as a device for redistributing rents from domestic en-

\footnotetext{
${ }^{1}$ New York Times, November 17, 2005, p. A30.

${ }^{2}$ For example, in 2002, a senior Congressional aide justified proposals to reform taxation of offshore income by "the need to make tax policy changes so that US businesses are no longer attractive takeover targets." Quoted in Collins and Shackelford (2003).
} 
trepreneurs to workers, despite the distortionary effects on investment. ${ }^{34}$

This view of the corporate tax has rather stark implications for the effects of multinational tax avoidance. Since the burden of multinational taxes is ultimately borne by domestic agents anyway, revenue losses due to tax planning are irrelevant, and what matters is the effect of tax planning on the level of multinational investment in high-tax countries and its deadweight costs for the economy, if any. Indeed, we show that an increase in income shifting causes the effective tax rate on capital to rise rather than fall, if the initial statutory tax rate is no greater than 50 per cent. According to recent OECD statistics, combined corporate and personal tax rates on equity capital in $\mathrm{G} 7$ countries range between 45 and 64 per cent, with a median value of 52 per cent. In loose terms, then, our theory predicts tax rates to remain roughly stable at current levels in response to the rise of tax havens, rather than to decline as in the standard view.

Our paper contributes to a growing theoretical literature on the relationship between tax planning and investment locations, and its implications for tax policies. Grubert and Slemrod (1998) point out that income shifting and real business location decisions of multinational firms may be interlinked in complex ways, and their theoretical model is the point of departure for our research. Haufler and Schjelderup (2000) observe that income shifting may induce governments to eliminate investment allowances to offset revenue losses, and so cause effective tax rates on capital to rise. Mintz and Smart (2004) point out that international tax planning may have positive effects on real investment that can offset the negative consequences of lost revenue. In their model, unlike ours, governments in high-tax countries nevertheless prefer to eliminate tax planning loopholes and reduce statutory corporate tax rates in order to achieve the same level of inward investment at a lower aggregate deadweight cost to the economy. Bucovetsky and Haufler (2005) also consider a model of income shifting and investment by multinationals. They examine the implications of tax sheltering for the decisions of firms to use multinational organizational structures, and for the potential for international tax cooperation.

Since the first version of our paper appeared, Slemrod and Wilson (2006) have also studied tax competition in the presence of income shifting in a re-

\footnotetext{
${ }^{3}$ Related, Gordon and MacKie-Mason (1995) observe that the corporation income tax serves to reduce domestic shifting between personal and corporate tax bases. But their analysis ignores capital.

${ }^{4}$ Of course, the corporate tax also has an indirect influence on redistribution through its effects on equilibrium wages in the economy, and our first result establishes conditions under which the optimal corporate tax rate is positive in a small, open economy.
} 
lated theoretical framework. They conclude that the presence of income shifting to tax havens reduces welfare in high-tax countries, precisely contrary to our main result. We provide a fuller description of their work below and attempt to account for the differences in results.

Section 2 lays out a two-sector general equilibrium model of corporate income taxation in a small, open economy. In this environment, corporate taxes can have desirable effects on the extent of income redistribution between domestic capitalists and domestic workers, but have deleterious effects on the level of foreign direct investment and on domestic wages. We establish necessary and sufficient conditions for the first effect to dominate, so that an optimizing government chooses a positive tax rate. In Section 3 , we introduce international tax avoidance, in the form of intra-corporate borrowing between the affiliate in the high-tax host country and an affiliate in a tax haven. We consider the effects of tax avoidance on the optimal tax policy of the host country and the welfare of its workers and capitalists. Section 4 introduces deadweight costs of tax planning activity and considers the case for thin capitalization rules that limit the extent of tax planning. Section 5 concludes with a comparison of our results with Slemrod and Wilson (2006) and a discussion of the implications for public policy.

\section{International taxation and domestic redistribution}

\subsection{The model}

Initially we study the effects of international taxation in the absence of income shifting. Our goal is to understand why governments may levy a source-based corporation income tax even in a small, open economy that earns no rents from the use of multinational capital stocks.

Consider therefore an economy consisting of two classes of consumersworkers and entrepreneurs-and a single, homogeneous consumption good that can be produced with either of two technologies. The first, available in what we label the multinational sector, produces output using domestic labour $L_{m}$ and imported capital $K$ according to a strictly concave, constantreturns production function $F\left(L_{m}, K\right)$, where we assume

$$
\lim _{K \rightarrow 0} F_{K}(L, K)=+\infty
$$

The second technology, owned by entrepreneurs in the domestic sector, employs labour $L_{d}$ and domestic entrepreneurial capital $D$ to produce output $G\left(L_{d}, D\right)$, where $G$ is a strictly concave, constant-returns function. 
Labour is immobile internationally but mobile between domestic and multinational sectors and earns wage rate $w$. The aggregate labour endowment of workers in the domestic economy is inelastically supplied, and we normalize it to one. The supply of domestic entrepreneurial capital $D$ is likewise fixed, so that the entrepreneurial class (who supply no labour) consume the rents accruing in the domestic sector after payment of taxes.

Capital $K$ used in the multinational sector is financed through equity injections from offshore parents, which in turn hire capital in the world market at fixed rental price $r$. That is, the economy is a small, open economy. The output of the two sectors may be absorbed domestically or exported at a fixed world price, normalized to one. Government levies a "classical" corporate income tax on the two sectors; that is, the tax base is firms' gross revenues less wage payments, and dividends remitted by multinationals to their parents are not deductible. Given the corporate tax rate $t$, firms in the multinational sector therefore maximize after-tax profit

$$
(1-t)\left(F\left(L_{m}, K\right)-w L_{m}\right)-r K
$$

Capital and labour demands therefore satisfy the first-order conditions

$$
\begin{aligned}
F_{K}\left(L_{m}, K\right) & =\frac{r}{1-t} \\
F_{L}\left(L_{m}, K\right) & =w
\end{aligned}
$$

To simplify subsequent notation, let $\rho=r /(1-t)$ denote the after-tax user cost of capital in the multinational sector, given by (1). Since capital is not employed in the domestic sector, the corporate tax there acts as a (lumpsum) tax on entrepreneurial rents

$$
\pi(w)=\max _{L_{d}} G\left(L_{d}, D\right)-w L_{d}
$$

(where we suppress the dependence of $\pi$ on the fixed entrepreneurial capital stock $D$ ), and labour demand in the domestic sector satisfies the firstorder condition

$$
G^{\prime}\left(L_{d}, D\right)=w
$$

Given $t$ and the optimizing decisions of firms, corporate tax revenues may be calculated as

$$
\begin{aligned}
T & =t\left(F\left(L_{m}, K\right)-w L_{m}\right)+t\left(G\left(L_{d}, D\right)-w L_{d}\right) \\
& =(\rho-r) K(w, \rho)+t \pi(w)
\end{aligned}
$$


where we have used (3) and the zero-profit condition of multinational firms $F-w L_{m}=\rho K$.

Let $w(\rho)$ be the wage rate that clears the domestic labour market

$$
L_{m}(w, \rho)+L_{d}(w, D)=1
$$

where $L_{d}$ and $L_{m}$ are the derived profit-maximizing demands satisfying (1)(4). Applying the implicit function theorem to (6) shows that $d w / d \rho \equiv$ $w_{\rho}^{\prime}<0$ : an increase in the user cost of capital induces a decline in the equilibrium wage rate, since (a fortiori) capital and labour are complements in the multinational sector.

A key simplifying assumption of our model is that the tax authority cannot observe the investment level of an individual firm, nor whether it is of the domestic or multinational type-and so is constrained to impose the same tax rate on all firms. In the sequel, income shifting by multinational firms will therefore create a wedge in the effective tax rates on capital paid by the two types of firms. Naturally, this role for income shifting would be attenuated, but not eliminated, if authorities could imperfectly observe the type of individual firms and hence their degree of international mobility, and customize their tax policies accordingly.

\subsection{Optimal tax policy}

Let us suppose that government seeks to redistribute income from the entrepreneurial class to the worker class, and that revenues from taxing both domestic and multinational firms are simply paid to workers as a lump sum. To capture the redistributive motive in a simple way, we suppose that government places a parametric value $\beta \leq 1$ on the consumption of entrepreneurs, relative to the consumption of workers. The objective function of the government is therefore $\Omega=C_{W}+\beta C_{E}$, where

$$
\begin{aligned}
C_{W} & =w+T \\
C_{E} & =(1-t) \pi(w)
\end{aligned}
$$

are consumption levels of workers and entrepreneurs, and $T$ is corporate tax revenues. More convenient for our purposes, define

$$
Y=F\left(L_{m}, K\right)-r K+G\left(L_{d}, D\right)
$$


as gross national product, and note that the material balance condition ${ }^{5}$ for the economy $C_{W}+C_{E}=Y$ allows us to write the government's problem as

$$
\begin{aligned}
& \max _{t \leq 1} Y(w, \rho)-(1-\beta) C_{E}(t, w) \\
& \text { subject to } \rho=\frac{r}{1-t} \\
& \text { and } L_{m}(w, \rho)+L_{d}(w, D)=1
\end{aligned}
$$

That is, government in this economy seeks to maximize GNP minus a fraction $(1-\beta)$ of net-of-tax profits that accrue to entrepreneurs. This formulation illustrates in a particularly stark way the equity-efficiency tradeoff that is at the heart of our model: the only means of redistribution from domestic entrepreneurs to domestic workers is the corporate tax, which distorts inward FDI and causes GNP to fall below its maximal level.

At an interior solution, an optimal tax rate $t^{*}$ therefore satisfies the firstorder necessary condition

$$
-\frac{d Y}{d t}=-(1-\beta) \frac{d C_{E}}{d t}
$$

The left-hand side of this expression is the marginal deadweight loss of the tax, which is equated to its marginal redistributive benefit at the optimum. The marginal deadweight loss can be computed by totally differentiating (9) with respect to $t$ and using (1), (2) and (4) to obtain

$$
\frac{d Y}{d t}=(\rho-r) \frac{\partial K}{\partial \rho}
$$

and (10) can then be rearranged to obtain a typical inverse-elasticity expression for the optimal tax rate:

$$
\frac{t^{*}}{1-t^{*}}=-\frac{1-\beta}{\rho K} \frac{1}{\epsilon_{K}} \frac{d C_{E}}{d t}
$$

where $\epsilon_{K}=-\rho K_{\rho}^{\prime} / K$ is the elasticity of capital demand with respect to its user cost.

To understand the implications of (11), it is useful first to consider a number of special cases. First, observe that, if there were no domestic sector $\left(C_{E} \equiv 0\right)$ then the optimal corporate tax rate would be zero. This replicates

\footnotetext{
${ }^{5}$ The material balance condition for this economy is merely Walras's law, and can be verified from (5)-(8) and the zero-profit condition for multinational firms.
} 
the standard result that a small open economy prefers taxes on domestic factors to taxes on imported capital. Second, if the government did not wish to redistribute from entrepreneurs to workers $(\beta=1)$ then the optimal corporate tax rate would again be zero. Without the redistribution motive, there is again no reason to tax or subsidize capital, since this would merely distort the multinational investment decision and labour market as well, as taxes on imported capital were shifted backward to domestic workers. Third, the optimal tax rate approaches to zero as the user-cost elasticity of international capital demand $\epsilon_{K}$ becomes large, so that the excess burden of the corporate tax becomes prohibitive.

Thus in our model the optimal corporate tax rate in a small, open economy is not zero, but it may in principle be either positive or negative. Equation (11) shows that the sign of $t^{*}$ is the same as the sign of the redistributive benefit of the tax, $-d C_{E} / d t$. This can in turn be computed from (3) and (10) as

$$
-\frac{d C_{E}}{d t}=\pi-\rho L_{d} \frac{d w}{d \rho}
$$

The first term measures the direct redistributive effect of taxing entrepreneurial profits and transferring the revenues to workers. The second is the indirect or general-equilibrium redistributive effect of the corporate tax, resulting from its deterrence of foreign direct investment, which decreases the wage and increases pre-tax entrepreneurial profits. Thus redistribution via a corporate tax occurs both post-fisc, through the transfer of revenues, and pre-fisc, through the effect on wages, and the two effects are offsetting. Put differently, the government in this small, open economy prefers greater multinational investment for its effect in enhancing domestic wages, and it recognizes that taxes on capital are ultimately incident on domestic workers rather than the owners of capital. The government may nevertheless tax corporate incomes in order to redistribute from domestic entrepreneurs to domestic workers.

In principle, if the indirect effect of the corporate tax dominates the direct effect, then the optimal corporate tax rate is negative: foreign direct investment should be subsidized to raise wages, even at the expense of the resulting transfers to domestic entrepreneurs. To determine which effect dominates, we show in the appendix that:

\section{Lemma 1}

$$
-\frac{d C_{E}}{d t}=L_{d}\left(\frac{G\left(L_{d}, D\right)}{L_{d}}-\frac{F\left(L_{m}, K\right)}{L_{m}}\right)
$$


Using Lemma 1, we may write the optimal tax formula (11) as

$$
\frac{t^{*}}{1-t^{*}}=\frac{1-\beta}{\epsilon_{K}} \frac{L_{d}}{\rho K}\left(\frac{G}{L_{d}}-\frac{F}{L_{m}}\right)
$$

That is, our model implies:

Proposition 1 The optimal corporate income tax rate is positive if and only if, evaluated at the optimum point, output per worker is greater in the domestic sector than in the multinational sector.

The proposition gives a (local) necessary and sufficient condition for the direct effect on redistribution to outweigh the indirect effect, and so for the optimal corporate tax rate to be positive at the optimum in the model. The condition is intuitive: when the multinational sector is relatively labour intensive, capital market distortions are of relatively little importance to labour demand, and redistribution is better achieved through the fisc than by subsidizing capital. As a loose heuristic, the condition says that international call centres are an appropriate target for host country taxation, while international financial centres should be subsidized.

Indirect redistributive effects in this model are particularly strong because of our assumption that the outputs of domestic and multinational sectors are perfect substitutes in consumption. A more realistic framework would allow for imperfect substitutability, which would attenuate the indirect effect and allow scope for positive corporate taxation even if labour intensities were (somewhat) reversed. For our purposes, however, it will suffice to assume that the condition of Proposition 1 holds at the optimum, so that $t^{*}>0$ in the absence of international tax planning. We now proceed to analyze how optimal tax policies change when multinational firms may shift offshore income earned domestically and so escape some portion of domestic tax liabilities.

\section{Optimal taxation with international tax planning}

To incorporate international tax avoidance behaviour in a simple way, we simply posit that each multinational firm has an affiliate located in a "tax haven" jurisdiction, and the firm may finance investment in the (high-tax) host country through a loan from the haven affiliate, rather than a direct equity injection from the parent. Since the host country operates a classical corporation income tax, interest payments to the haven affiliate are 
deductible from host country taxable income. We assume that the haven imposes no taxes at all on income remitted there, though none of our qualitative results would change if the haven levied some positive but lower tax rate than the host country. ${ }^{6}$

Since the interest payment to the haven affiliate is $r B$, the firm's after-tax profit is therefore

$$
\Pi=(1-t)(F-w L)-r K+\operatorname{tr} B
$$

That is, the possibility of lending between affiliates facing different tax rates creates an unlimited tax arbitrage opportunity. More realistically, even related-party borrowing creates deadweight costs for the firm and its outside investors, which reflect the transactions costs of these strategies, the potential for affiliate default, and the agency problems associated with the complex financial structures that international tax planning entails ("Parmalat costs"). ${ }^{7}$ Such costs serve as a brake on international tax planning and, to capture this in a simple way, we simply assume for now that the firm is constrained not to issue debt to the haven affiliate in excess of an exogenous debt-capital ration $b$ : the $B \leq b K$. We return to an analysis of agency costs below in Section 4.

Since the debt constraint will bind at the optimum, we may substitute it into the profit function to obtain

$$
\Pi\left(L_{m}, K\right)=(1-t)\left[F\left(L_{m}, K\right)-w L_{m}-\frac{r(1-b t)}{1-t} K\right]
$$

Profit-maximizing input demands therefore again satisfy $F_{L}=w$ and $F_{K}=\rho$ where now the user cost of capital is

$$
\rho(t, b)=\frac{r(1-b t)}{1-t}
$$

while the domestic sector's labour demand is still characterized by $G^{\prime}\left(L_{d}, D\right)=$ $w$.

\footnotetext{
${ }^{6}$ More restrictive is our assumption that the haven's tax rate is exogenous, and independent of the degree of multinational income shifting that takes place. That is, we study the optimal tax policies of a single high-tax country, rather than a tax-competition game among countries. However, Janeba and Peters (1999) and Marceau et al. (2006) study the emergence of tax havens in a two sector model of tax competition that has some similarity to our environment. They show that even small differences in technologies between countries can lead to large differences in equilibrium tax rates on mobile tax bases.

${ }^{7}$ Desai et al. (2004a) provide a discussion of such costs and the effects of international tax planning in Russia.
} 
The consequence of tax planning is to reduce the host country's tax revenues from $t(\pi+r K /(1-t))$ in the absence of the tax haven to

$$
T=t\left(\pi+\frac{1-b}{1-t} r K\right)
$$

and so at a fixed tax rate to reduce the consumption of domestic workers. However, this ignores the optimal response in tax policies to income shifting, which we turn to next.

To study optimal policy, it is more convenient to formulate the problem as one of choosing an effective tax rate on capital $\rho-r$, rather than a statutory rate $t$. Accordingly, define the statutory tax rate associated with any user cost of capital by

$$
t=g(\rho, b) \equiv \frac{\rho-r}{\rho-r b} \Longleftrightarrow \rho=\rho(t, b)
$$

Observe that $g$ is increasing in $(\rho, b)$. In the presence of income shifting, then, the host government's optimal tax policies solve: ${ }^{8}$

$$
\begin{aligned}
& \Omega^{*}(b)=\max _{\rho} Y(w, \rho)-(1-\beta) C_{E}(t, w) \\
& \text { subject to } t=g(\rho, b) \\
& L_{m}(w, \rho)+L_{d}(w, D)=1
\end{aligned}
$$

The first-order necessary condition is

$$
(\rho-r) \frac{\partial K(w, \rho)}{\partial \rho}+(1-\beta)\left[\pi \frac{\partial g(\rho, b)}{\partial \rho}+(1-t) L_{d} \frac{\partial w(\rho)}{\partial \rho}\right]=0
$$

which can be inverted to obtain an optimal tax formula analogous to (11) for the no-shifting case. ${ }^{9}$

\footnotetext{
${ }^{8}$ Given constant returns to scale in the multinational sector, and using (6)-(8) and (15), the material balance condition for the economy is again $C_{W}+C_{E}=Y=F-r K+G$, and the government's objective can be written as $Y-(1-\beta) C_{E}$.

${ }^{9}$ After some tedious manipulation, (16) can be reduced to

$$
\frac{t^{*}}{1-t^{*}}=\frac{(1-\beta) L_{d}}{\rho K \epsilon}\left(\frac{G}{L_{d}}-\frac{F}{L_{m}}\right)+(1-\beta)\left(1-t^{*}\right) \frac{b}{1-b} \frac{\pi}{\rho K \epsilon}
$$

where $t^{*}$ is the optimal tax rate in the no-shifting case. Since $t^{*} \leq 1$, the second term is non-negative, and the sufficient condition of Proposition 1 for a positive optimal tax rate is sufficient in the case with international tax planning as well.
} 
Our first substantive result concerns the effect of income shifting on the marginal effective tax rate on capital $\rho^{*}-r$ that solves (16). Totally differentiating (16),

$$
\frac{\partial \rho^{*}}{\partial b} \geq 0 \quad \Longleftrightarrow \quad(1-\beta) l_{d} \frac{K}{L_{m}} \frac{\partial g\left(\rho^{*}, b\right)}{\partial b}+(1-\beta) \pi \frac{\partial^{2} g\left(\rho^{*}, b\right)}{\partial \rho \partial b} \geq 0
$$

The first term on the left-hand side of this expression is the impact of income shifting on pre-fisc income inequality. As before, the tax on multinational capital depresses wages and redistributes to entrepreneurs, but income shifting permits an increase in the statutory tax rate $(\partial g / \partial b>0)$, which mitigates the effect of lower wages on an after-tax basis. The second term is the impact of income shifting on the capital distortion caused by increases in the statutory tax rate. In the appendix we show this term is positive $\left(\partial^{2} g / \partial \rho \partial b \geq 0\right)$ if and only if the initial tax rate is no greater than 50 per cent. Thus we have:

Proposition 2 An increase in international tax planning $b$ causes an increase in the optimal marginal effective tax rate on capital $\rho^{*}-r$, and a decline in foreign direct investment if $t^{*} \leq 1 / 2$.

Proof. See appendix.

Furthermore, since

$$
\frac{\partial t^{*}}{\partial b}=\frac{\partial g\left(\rho^{*}, b\right)}{\partial \rho} \frac{\partial \rho^{*}}{\partial b}+\frac{\partial g\left(\rho^{*}, b\right)}{\partial b}>0 \quad \text { if } \quad \frac{\partial \rho^{*}}{\partial b} \geq 0
$$

we may immediately establish:

Proposition 3 An increase in international tax planning $b$ causes an increase in the statutory tax rate $t^{*}$ if $t^{*} \leq 1 / 2$.

Our results suggest a new view of international tax planning and its effects on high-tax countries. The standard view is that the rise in income shifting may lead to an erosion in corporate tax revenues, and a decline in statutory rates as high-tax countries compete to protect tax bases, with a consequent decline in consumer welfare. However, while multinational corporate tax revenues decline with greater ease of income shifting, this is without direct consequence for consumers in a small, open economy, since the burden of such taxes is shifted to other agents in any case. The indirect consequence is the decline in effective taxes on foreign direct investment, 


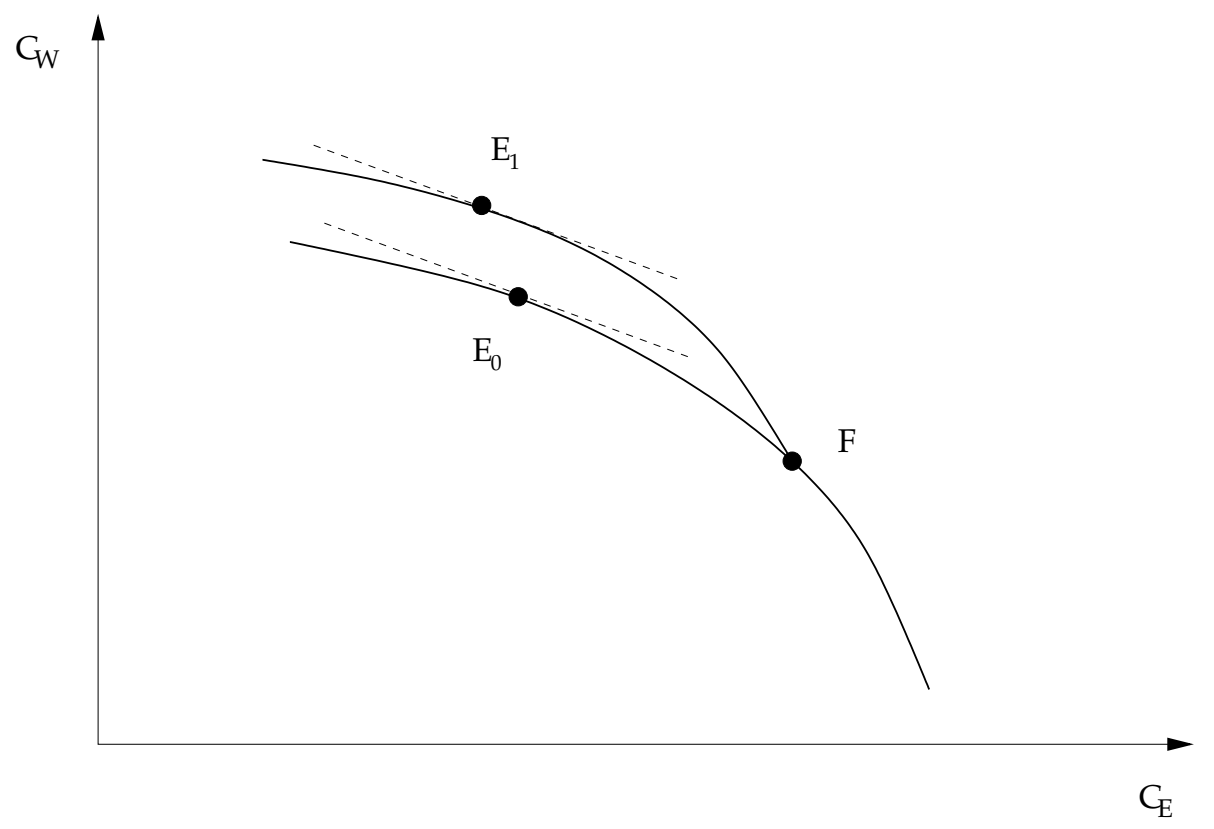

Figure 1: The effect of income shifting on the optimal allocation

and so an opportunity to increase statutory rates with reducing foreign investment. Proposition 3 shows that statutory rates will indeed increase, if the initial rate is not too high. More surprising perhaps, Proposition 2 implies that under the same conditions it is optimal to increase the statutory rate so much that the increase more than offsets the effect of income shifting, the effective tax on foreign capital rises, and investment declines in consequence.

Figure 1 illustrates the result in consumption space. To do so, define the utility possibility frontier for this economy given the extent of income shifting $b$ by the set

$$
\mathcal{F}(b)=\left\{\left(C_{E}, C_{W}\right) \in \mathbf{R}_{+}^{2}: \exists t \text { such that } C_{E}=C_{E}^{*}(t, b) \text { and } C_{W}=C_{W}^{*}(t, b)\right\}
$$

where the consumption levels of the two classes of agents are given by the individual budget constraints (7)-(8), given the equilibrium wage $w(\rho)$.

Figure 1 depicts the utility possibility frontier for two different values of $b$. The curve labeled $E_{0} F$ is the utility possibility frontier for some initial degree of income shifting $b_{0}$. The point $F$, where the slope of the UPF is -1 , corresponds to a statutory tax rate of zero; the point $E_{0}$, where the slope of the UPF is $-\beta$, is the optimal allocation, corresponding to some positive 
statutory tax rate $t_{0}^{*}$ under the conditions of Proposition 1 . Now consider an increase in feasible income shifting to $b_{1}>b_{0}$, and suppose that the host government responds by holding the user cost of capital constant at $\rho_{0}^{*}$. Then GNP and the pre-tax wage would remain unchanged, but $t$ would rise to keep $\rho$ constant, so that $C_{E}$ would fall and $C_{W}$ would rise. Consequently, the UPF for $b_{1}$ includes a feasible point that lies to the northeast of $E_{0}$. As well, point $F$ lies on the new UPF, since $b$ is irrelevant to the allocation when $t=0$. Consequently, an increase in $b$ causes the UPF to shift outward to the left of $F$, to a curve such as the one labeled $E_{1} F$.

Thus $C_{W}$ must increase with $b$, as illustrated in Figure 1 . This result is based on revealed-preference considerations alone, and so it does not depend on the particular welfare function we assume, nor the technologies of firms. But worker consumption may increase through a decline in the user cost of foreign capital and an increase in domestic wages, or through an increase on rents transferred from domestic entrepreneurs through the statutory tax rate, or both. Which of these occurs in response to an increase in $b$ depends on the specifics of the model, as shown in Proposition 2.

It is also apparent from Figure 1 that domestic social welfare $\Omega$ must increase with $b$. This may be verified by applying the envelope theorem to obtain

$$
\frac{\partial \Omega}{\partial b}=(1-\beta) \pi \frac{\partial g\left(\rho^{*}, b\right)}{\partial b}>0
$$

since $\partial g / \partial b>0$. Thus we have:

Proposition 4 An increase in international tax planning $b$ causes social welfare to rise in a high-tax country.

The result suggests that high-tax governments may rationally be reluctant to take steps to combat international tax planning. In view of Proposition 4, tax planning by multinational firms is an unmitigated boon to hightax countries, and no restrictions are warranted. But our analysis thus far has ignored the deadweight costs of tax planning - the subject of the next section, which offers a more nuanced view of restrictions on tax planning.

Since the effect of income shifting in our model is to reduce the excess burden of redistributive taxation, it might be expected that its effect is a Pareto improvement for citizens of the host country, and not merely a welfare gain. But this is not the case: To see the effect of shifting on the consumption of domestic entrepreneurs, totally differentiate $C_{E}^{*}(t, b) \equiv$ $(1-t) \pi(w(\rho(t, b)))$ to obtain

$$
d C_{E}=\frac{\partial C_{E}^{*}}{\partial t} d t^{*}-\left(1-t^{*}\right) L_{d} w^{\prime}\left(\rho^{*}\right) \frac{\partial \rho\left(t^{*}, b\right)}{\partial b} d b
$$


Since Proposition 1 implies $\partial C_{E}^{*} / \partial t<0$ for $t^{*}>0, \partial \rho / \partial b<0$, and Proposition 3 implies $\partial t^{*} / \partial b>0$ if $t^{*} \leq 1 / 2$, we have:

Proposition 5 An increase in international tax planning $b$ causes the utility of domestic entrepreneurs to fall if $0 \leq t^{*} \leq 1 / 2$.

\section{Restrictions on tax planning}

The analysis of the preceding section interprets international tax planning as an exogenous influence on the tax policy of governments, and parameterizes the effect by the fraction of multinational profits that can be shifted to havens through related-party borrowing. Underlying the model is the notion that managers and shareholders themselves prefer to limit income shifting, because of the agency and other deadweight costs it imposes on the firm. In this section, we introduce an explicit (though very simple) model of the deadweight costs of tax planning, and we ask whether governments in hightax countries prefer to restrict such activities beyond the natural restraints deadweight costs place on the firms themselves.

In fact, governments in high-tax countries do attempt to control multinational financing structures through a variety of means. A number of countries in particular impose thin capitalization rules on foreign-controlled corporate taxpayers, which limit the deductibility of interest and so the extent of income shifting through debt.Our chief result in this section therefore characterizes the optimal thin capitalization rule from the perspective of a high-tax country.

The model is the same as in Section 3, except that borrowing $B$ from the haven affiliate entails real deadweight costs $C(B, K)$. Assume that $C$ is differentiable, increasing and convex in $B$, and linear-homogeneous in its arguments. Accordingly, let $C(B, K)=c(r b) K$, where $b=B / K$ is the debtcapital ratio, and $c(r b)$ is the cost per unit of capital owned by the affiliate in the high-tax country. Assume moreover that $c(0)=c^{\prime}(0)=0$ : informally, the deadweight cost of the first dollar of income shifted is arbitrarily small.

The firm chooses $b$ and $K$ to maximize after-tax profits net of shifting costs, given by

$$
(1-t)\left[F\left(L_{m}, K\right)-w L_{m}\right]-[r(1-t b)-c(r b)] K
$$

Maximizing (17) with respect to $b$, in the absence of thin capitalization rules, the optimal debt-capital ratio of the firm therefore satisfies

$$
t=c^{\prime}\left(r b^{*}\right)
$$


since the tax arbitrage benefit of borrowing is equated to its marginal cost at the optimum. Observe that $b^{*}$ is increasing in $t$, since $c^{\prime}$ is increasing. The firm's factor demands satisfy the usual conditions $F_{K}=\rho$ and $F_{L}=w$, where now the user cost of capital is

$$
\rho(t, b)=\frac{r(1-t b)+c(r b)}{1-t}
$$

Consider now a thin capitalization restriction on the high-tax affiliate's deductible interest expenses as a proportion of capital:

$$
r B \leq \gamma K
$$

for some $\gamma \in[0,1]$. To focus on the interesting case, assume that $\gamma \leq r b^{*}$, so the limit is binding at the firm's optimum.

The host government now has two policy instruments, the effective tax rate on capital $\rho-r$ and the limit on interest deductions $\gamma$. The government's objective function is now

$$
\Omega(\rho, t, \gamma)=Y(w, \rho)-(1-\beta) C_{E}(t, w)-c(\gamma) K
$$

since GNP is net of the deadweight costs of shifting; and $(\rho, t, \gamma)$ are to be chosen to maximize $\Omega$ subject to (19) and the equilibrium conditions for the economy.

Let $t=g(\rho, \gamma)$ denote the inverse tax function for (19). The optimal thin capitalization rule $\gamma^{*}$ satisfies the first-order condition

$$
\Omega_{\gamma}^{\prime}=(1-\beta) \pi \frac{\partial g\left(\rho^{*}, \gamma^{*}\right)}{\partial \gamma}-c^{\prime}\left(\gamma^{*}\right) K=0
$$

together with the condition analogous to (16) for $\rho^{*}$. Observe from (20) that the impact of the thin capitalization rule can be decomposed into its effect on domestic redistribution (the first term) and on deadweight costs (the second term). The first effect is positive, since $g_{\gamma}^{\prime}>0$-facilitating income shifting permits an increase in the statutory tax rate and so in domestic redistribution-while the second is negative. Under our assumptions, we may demonstrate that the optimal thin capitalization rule is interior: In the presence of deadweight costs, some tax planning is desirable, but so are some restrictions on it:

Proposition 6 The socially optimal degree of tax planning is positive but less than that preferred by multinational firms: $0<\gamma^{*}<r b^{*}$.

Proof. See appendix. 


\section{Conclusion}

Our results suggest a new view of the role of tax havens in international competition for business tax bases. While income shifting to tax havens may reduce revenues of high-tax jurisdictions and increase tax base elasticities, it tends to make the location of real investment less responsive to tax rate differentials. In principle, then, the presence of international tax planning opportunities may allow countries to maintain or even increase high business tax rates, while preventing an outflow of foreign direct investment. Indeed, we have shown that the investment-enhancing effects of international tax planning can dominate the revenue-erosion effects: an increase in international tax avoidance can lead to an increase in both statutory and effective tax rates on capital, if initial tax rates are not too high, and an increase in the welfare of citizens of high-tax countries.

In a recent contribution, Slemrod and Wilson (2006) also study the effects of income shifting to tax havens in a model of tax competition. As in our work, they consider a small, open economy model of capital flows, in which a reduced-form model of international income shifting is posited; as in our work, they introduce an interaction between the multinational capital tax base and domestic income tax bases that generates a positive tax rate on capital in the equilibrium of the model. Despite these similarities, Slemrod and Wilson conclude that the presence of income shifting to tax havens reduces welfare in high-tax countries, precisely contrary to our main result.

Given that such similar frameworks lead to such different normative conclusions, it is worthwhile exploring the differences between the models in more detail. In Slemrod and Wilson, governments have access to two tax bases, mobile capital and domestic labour, and they are free to tax either base at any rate. ${ }^{10}$ In this setting, the standard result is that, since both taxes are ultimately incident on domestic labour anyway, governments in equilibrium set the tax on capital to zero, relying exclusively on labour taxation to finance spending, even if labour taxes have their own distortionary cost due to domestic tax avoidance activities. The wrinkle in Slemrod and Wilson (2006) is that a reduced-form model of domestic tax evasion is introduced. Since labour taxes can be evaded, a reduction in the after-tax wage through labour taxation creates deadweight costs that a reduction in the pretax wage through discouraging capital investment does not. Consequently, governments prefer to rely to some extent on capital taxes in equilibrium,

\footnotetext{
${ }^{10}$ The notion that corporate income taxes are both taxes on capital and taxes on the labour of high-income entrepreneurs, central to our analysis, is absent from their work.
} 
despite their wage-reducing effects.

In this context, introduction of income shifting activities is akin to an increase in the elasticity of national tax bases in the standard model, which Slemrod and Wilson show to intensify tax competition among countries, to reduce equilibrium tax rates on the mobile base and public goods provision, and so to reduce welfare for residents of high-tax countries in equilibrium.

Choice between the two models must naturally be made on the basis of their implications about observables, rather than their normative implications. While Slemrod and Wilson do not emphasize implications of their model that correspond closely to our main testable implications, Propositions 2 and 3, some inferences may readily be drawn. In the Slemrod-Wilson model, introduction of tax havens must lead to a decline in equilibrium statutory tax rates, whereas our theory predicts higher statutory rates with shifting to havens and even higher effective tax rates on capital investment, if statutory tax rates are no higher than 50 per cent-about the current average level of corporate and personal tax rates on equity in OECD countries. A straightforward way to distinguish between the models, therefore, is to determine whether the rise of income shifting has caused a reduction in effective tax rates or not. Consistent with our theory, Devereux et al. (2002) and Slemrod (2004) have found no evidence of a decline in marginal effective tax rates on capital in OECD countries in recent years, although this reflects both a decline in statutory corporate tax rates and reductions in investment allowances. Of course, attributing any of these changes to the causal effects of competition from havens is more difficult.

Another, albeit less direct, way to distinguish between the theories is in their implications for the desirability of restrictions on tax planning. In the Slemrod-Wilson theory, restrictions are unambiguously welfare improving; in our theory, some degree of restriction improves welfare, but it is never optimal to eliminate tax planning entirely. This view may therefore rationalize those aspects of the aspects of the corporate tax systems in some high-tax countries that appear to target tax reductions to mobile, multinational firms (Bucovetsky and Haufler, 2005). For example, Ireland's lowtax policies have made it a magnet for headquarters operations in Europe but have drawn little policy response from the European Union, despite the demonstrated willingness of member states to harmonize tax policies in other areas. In the United States, concerns about expatriation of corporate ownership to havens appear to have prompted reforms aimed at reducing tax liabilities on worldwide income of US taxpayers. While future growth in haven activities may bring a more concerted policy response from high-tax countries, the case at present is far from clear. 


\section{Appendix}

Proof of Lemma 1. Equation (11) establishes that

$$
\frac{t^{*}}{1-t^{*}}=-\frac{(1-\beta)}{\rho K} \frac{1}{\epsilon_{K}} \frac{d C_{E}}{d t}
$$

where the general equilibrium decline in entrepreneurs' consumption $C_{E}=$ $(1-t) \pi(w(\rho))$ from raising the corporate tax is

$$
-\frac{d C_{E}}{d t}=\pi+(1-t) L_{d} w_{\rho}^{\prime} \rho_{t}^{\prime}=\pi+L_{d} \rho w_{\rho}^{\prime}
$$

where $w(\rho)$ is the equilibrium wage of labour in the economy given the user cost of capital $\rho$.

Recall that, given the government's choice of user cost $\rho$, the equilibrium wage solves the system of equations:

$$
\begin{aligned}
F_{L}\left(L_{m}, K\right) & =w \\
F_{K}\left(L_{m}, K\right) & =\rho \\
G_{L}\left(L_{d}, D\right) & =w \\
L_{m}+L_{d} & =1
\end{aligned}
$$

Let $K^{*}\left(\rho, L_{m}\right)$ solve the first equation and note $K_{\rho}^{*}=1 / F_{K K}$ and $K_{L}^{*}=$ $-F_{L K} / F_{K K}$. We may therefore characterize equilibrium allocation of labour by:

$$
F_{L}\left(K^{*}\left(\rho, L_{m}\right), L_{m}\right)=G_{L}\left(1-L_{m}\right)
$$

Totally differentiating this condition gives

$$
F_{L K} K_{\rho}^{*} d \rho+\left(F_{L K} K_{L}^{*}+F_{L L}\right) d L_{m}=-G_{L L} d L_{m}
$$

or

$$
\frac{\partial L_{m}}{\partial \rho}=-\frac{F_{L K}}{\left(F_{L L}+G_{L L}\right) F_{K K}+\left(F_{L K}\right)^{2}}
$$

Since $F$ is linear homogeneous,

$$
\begin{aligned}
F_{L K} & =-\frac{L_{m}}{K} F_{L L} \\
& =-\frac{K}{L_{m}} F_{K K}
\end{aligned}
$$


and $\left(F_{L K}\right)^{2}=F_{L L} F_{K K}$, so

$$
\frac{\partial L_{m}}{\partial \rho}=-\frac{F_{L K}}{G_{L L} F_{K K}}=\frac{K}{L_{m}} \frac{1}{G_{L L}}
$$

Since $\partial w / \partial \rho=-G_{L L} \partial L_{m} / \partial \rho$,

$$
w_{\rho}^{\prime}=\frac{\partial w}{\partial \rho}=-\frac{K}{L_{m}}
$$

Substituting this expression into (21) yields

$$
\begin{aligned}
-\frac{d C_{E}}{d t} & =L_{d}\left[\frac{\pi}{L_{d}}-\frac{\rho K}{L_{m}}\right] \\
& =L_{d}\left[\frac{G-w L_{d}}{L_{d}}-\frac{F-w L_{m}}{L_{m}}\right] \\
& =L_{d}\left[\frac{G}{L_{d}}-\frac{F}{L_{m}}\right]
\end{aligned}
$$

where the second equality follows from the identity $\pi=G-w L_{d}$ and (given constant returns to scale in $F$ and Euler's theorem) $\rho K=F-w L_{m}$.

Proof of Proposition 2. Applying implicit function theorem to (16),

$$
\operatorname{sign} \partial \rho^{*} / \partial b=\operatorname{sign}\left[L_{d} \frac{K}{L_{m}} g^{\prime}\left(\rho^{*}, b\right)+\pi g_{\rho b}^{\prime \prime}\left(\rho^{*}, b\right)\right]
$$

Defining $t^{*}=g\left(\rho^{*}, b\right)>0$,

$$
\begin{aligned}
g_{b}^{\prime}\left(\rho^{*}, b\right) & =\frac{t^{*}\left(1-t^{*}\right)}{1-b}>0 \\
g_{\rho b}^{\prime \prime}\left(\rho^{*}, b\right) & =\frac{\left(1-2 t^{*}\right) r}{\left(\rho^{*}-r b\right)^{2}}
\end{aligned}
$$

Hence $g_{\rho b}^{\prime \prime}>0$ if and only if $t^{*} \leq 1 / 2$.

\section{Proof of Proposition 6.}

Observe first that, for any user cost of capital $\rho$, social welfare is a strictly concave function of $\gamma$ : Differentiating (20) with respect to $\gamma$ yields

$$
\Omega_{\gamma \gamma}^{\prime \prime}=-\frac{(1-\beta) \pi}{(\rho-\gamma)^{2}}\left(c^{\prime \prime}(\gamma)(\rho-\gamma)+2 c^{\prime}(\gamma)+2 t\right)-c^{\prime \prime}(\gamma) K<0
$$


since $c^{\prime \prime} \geq 0$.

Evaluating (20) at $\gamma=0$,

$$
\Omega_{\gamma}^{\prime}(\rho, t, 0)=(1-\beta) \pi \frac{t}{\rho}>0
$$

since

$$
\frac{\partial g(\rho, \gamma)}{\partial \gamma}=\frac{t-c^{\prime}(\gamma)}{\rho-\gamma}
$$

and $c(0)=c^{\prime}(0)=0$ by assumption. At the upper threshold of the range of binding restrictions on borrowing, $\hat{\gamma}=r b^{*}, c^{\prime}(\hat{\gamma})=t$, and

$$
\Omega_{\gamma}^{\prime}(\rho, t, \hat{\gamma})=-t K<0
$$

Since $\Omega$ is strictly concave in $\gamma$ for all $\rho$, it follows that $0<\gamma^{*}<r b^{*}$. 


\section{References}

Bucovetsky, Sam and Haufler, Andreas. "Tax competition when firms choose their organizational form: Should tax loopholes for multinationals be closed?" Technical Report 1625, CESifo 2005.

- and Wilson, John Douglas. "Tax competition with two tax instruments." Regional Science and Urban Economics, 1991, 21, pp. 333-350.

Collins, Julie H. and Shackelford, Douglas A. "Do US multinationals face different tax burdens than do other companies?" Tax Policy and the Economy, 2003, 17, pp. 141-168.

Desai, Mihir A.; Dyck, Alexander and Zingales, Luigi. "Theft and Taxes." Technical Report 10978, National Bureau of Economic Research 2004.

_ ; Foley, C. Fritz and Hines, James R. "Economic Effects of Regional Tax Havens." Technical Report 10806, National Bureau of Economic Research 2004.

Devereux, Michael P.; Griffith, Rachel and Klemm, Alexander. "Corporate Income Tax Reforms and International Tax Competition." Economic Policy, 2002, 35, pp. 451-495.

Gordon, Roger H. "Taxation of investment and savings in a world economy." American Economic Review, 1986, 76, pp. 1086-1102.

Gordon, Roger H and MacKie-Mason, Jeffrey K. "The importance of income shifting to the design and analysis of tax policy." in Martin Feldstein; James R Hines and R. Glenn Hubbard, eds., Taxing multinational corporations, University of Chicago Press, 1995, pp. 29-37.

Grubert, Harry and Slemrod, Joel. "The effect of taxes on investment and income shifting to Puerto Rico." Review of Economics and Statistics, 1998, 80, pp. 365-373.

Haufler, Andreas and Schjelderup, Guttorm. "Corporate Tax Systems and Cross-country Profit Shifting." Oxford Economic Papers, 2000, 52, pp. 306325.

Hines, James R and Rice, Eric M. "Fiscal paradise: Foreign tax havens and American business." Quarterly Journal of Economics, 1994, 109, pp. 149182. 
Janeba, Eckhard and Peters, Wolfgang. "Tax evasion, tax competition and the gains from non-discrimination: The case of interest taxation in Europe." Economic Journal, 1999, 109, pp. 93-101.

Marceau, Nicolas; Mongrain, Steeve and Wison, John D. "Why do most countries set high tax rates on capital?" Technical Report, Université du Québec à Montréal 2006.

Mintz, Jack and Smart, Michael. "Income shifting, investment, and tax competition: Theory and evidence from provincial taxation in Canada." Journal of Public Economics, 2004, 88, pp. 1149-1168.

Mintz, Jack M. "Conduit entities: Implications of indirect tax-efficient financing structures for real investment." International Tax and Public Finance, 2004, 11, pp. 419-434.

Slemrod, Joel. "Are corporate tax rates, or countries, converging?" Journal of Public Economics, 2004, 88, pp. 1169-1186.

- and Wilson, John D. "Tax competition with parasitic tax havens." Technical Report, University of Michigan 2006. 


\section{CESifo Working Paper Series}

(for full list see www.cesifo-group.de)

1880 Peter Huber, Michael Pfaffermayr and Yvonne Wolfmayr, Are there Border Effects in the EU Wage Function?, December 2006

1881 Harry Flam and Håkan Nordström, Euro Effects on the Intensive and Extensive Margins of Trade, December 2006

1882 Panu Poutvaara and Mikael Priks, Hooliganism in the Shadow of the 9/11 Terrorist Attack and the Tsunami: Do Police Reduce Group Violence?, December 2006

1883 Ruud A. de Mooij and Gaëtan Nicodème, Corporate Tax Policy, Entrepreneurship and Incorporation in the EU, December 2006

1884 Johannes Becker and Clemens Fuest, Corporate Tax Policy and International Mergers and Acquisitions - Is the Tax Exemption System Superior?, January 2007

1885 Momi Dahan and Udi Nisan, The Effect of Benefits Level on Take-up Rates: Evidence from a Natural Experiment, January 2007

1886 José García-Solanes, Francisco I. Sancho-Portero and Fernando Torrejón-Flores, Beyond the Salassa-Samuelson Effect in some New Member States of the European Union, January 2007

1887 Peter Egger, Wolfgang Eggert and Hannes Winner, Saving Taxes Through Foreign Plant Ownership, January 2007

1888 Timothy J. Goodspeed and Andrew Haughwout, On the Optimal Design of Disaster Insurance in a Federation, January 2007

1889 Wim Groot, Henriëtte Maassen van den Brink and Bernard van Praag, The Compensating Income Variation of Social Capital, January 2007

1890 Bas Jacobs, Ruud A. de Mooij and Kees Folmer, Analyzing a Flat Income Tax in the Netherlands, January 2007

1891 Hans Jarle Kind, Guttorm Schjelderup and Frank Stähler, Newspapers and Advertising: The Effects of Ad-Valorem Taxation under Duopoly, January 2007

1892 Erkki Koskela and Rune Stenbacka, Equilibrium Unemployment with Outsourcing under Labour Market Imperfections, January 2007

1893 Maarten Bosker, Steven Brakman, Harry Garretsen, Herman de Jong and Marc Schramm, The Development of Cities in Italy 1300 - 1861, January 2007

1894 Michel Beine, Oscar Bernal, Jean-Yves Gnabo and Christelle Lecourt, Intervention Policy of the BoJ: A Unified Approach, January 2007 
1895 Robert S. Chirinko and Daniel J. Wilson, State Investment Tax Incentives: A Zero-Sum Game?, January 2007

1896 Theo S. Eicher and Oliver Roehn, Sources of the German Productivity Demise Tracing the Effects of Industry-Level ICT Investment, January 2007

1897 Helge Berger, Volker Nitsch and Tonny Lybek, Central Bank Boards around the World: Why does Membership Size Differ?, January 2007

1898 Gabriel Felbermayr and Wilhelm Kohler, Does WTO Membership Make a Difference at the Extensive Margin of World Trade?, January 2007

1899 Benno Torgler and Friedrich Schneider, The Impact of Tax Morale and Institutional Quality on the Shadow Economy, January 2007

1900 Tomer Blumkin and Efraim Sadka, On the Desirability of Taxing Charitable Contributions, January 2007

1901 Frederick van der Ploeg and Reinhilde Veugelers, Higher Education Reform and the Renewed Lisbon Strategy: Role of Member States and the European Commission, January 2007

1902 John Lewis, Hitting and Hoping? Meeting the Exchange Rate and Inflation Criteria during a Period of Nominal Convergence, January 2007

1903 Torben M. Andersen, The Scandinavian Model - Prospects and Challenges, January 2007

1904 Stephane Dees, Sean Holly, M. Hashem Pesaran and L. Vanessa Smith, Long Run Macroeconomic Relations in the Global Economy, January 2007

1905 Richard Jong-A-Pin and Jakob De Haan, Political Regime Change, Economic Reform and Growth Accelerations, January 2007

1906 Sascha O. Becker and Peter H. Egger, Endogenous Product versus Process Innovation and a Firm's Propensity to Export, February 2007

1907 Theo S. Eicher, Chris Papageorgiou and Oliver Roehn, Unraveling the Fortunates of the Fortunate: An Iterative Bayesian Model Averaging (IBMA) Approach, February 2007

1908 Liliana E. Pezzin, Robert A. Pollak and Barbara S. Schone, Efficiency in Family Bargaining: Living Arrangements and Caregiving Decisions of Adult Children and Disabled Elderly Parents, February 2007

1909 Christian Keuschnigg and Soren Bo Nielsen, Self-Selection and Advice in Venture Capital Finance, February 2007

1910 Rune Jansen Hagen and Gaute Torsvik, Irreversible Investments, Dynamic Inconsistency and Policy Convergence, February 2007 
1911 Eric A. Hanushek and Ludger Woessmann, The Role of School Improvement in Economic Development, February 2007

1912 Bernard M. S. van Praag, Perspectives from the Happiness Literature and the Role of New Instruments for Policy Analysis, February 2007

1913 Volker Grossmann and Thomas M. Steger, Growth, Development, and Technological Change, February 2007

1914 Margarita Katsimi and Thomas Moutos, Human Capital and the Feldstein-Horioka Puzzle, February 2007

1915 Oliver Roehn, Theo S. Eicher and Thomas Strobel, The Ifo Industry Growth Accounting Database, February 2007

1916 Ian Babetskii, Aggregate Wage Flexibility in Selected New EU Member States, February 2007

1917 Burkhard Heer, Alfred Maussner and Paul D. McNelis, The Money-Age Distribution: Empirical Facts and Limited Monetary Models, February 2007

1918 Yin-Wong Cheung, Menzie D. Chinn and Eijii Fujii, The Overvaluation of Renminbi Undervaluation, February 2007

1919 Jim Malley, Apostolis Philippopoulos and Ulrich Woitek, To React or Not? Fiscal Policy, Volatility and Welfare in the EU-3, February 2007

1920 Mattias Polborn, Competing for Recognition through Public Good Provision, February 2007

1921 Lars P. Feld and Benno Torgler, Tax Morale after the Reunification of Germany: Results from a Quasi-Natural Experiment, February 2007

1922 Robert S. Chirinko and Huntley Schaller, Fundamentals, Misvaluation, and Investment: The Real Story, February 2007

1923 Benno Torgler and Friedrich Schneider, Shadow Economy, Tax Morale, Governance and Institutional Quality: A Panel Analysis, February 2007

1924 Adrian Pagan and M. Hashem Pesaran, On Econometric Analysis of Structural Systems with Permanent and Transitory Shocks and Exogenous Variables, February 2007

1925 Hans-Werner Sinn, The Welfare State and the Forces of Globalization, February 2007

1926 Michael Smart, Raising Taxes through Equalization, February 2007

1927 Øystein Foros, Kåre P. Hagen and Hans Jarle Kind, Price-Dependent Profit Sharing as an Escape from the Bertrand Paradox, February 2007 
1928 Balázs Égert, Kirsten Lommatzsch and Amina Lahrèche-Révil, Real Exchange Rates in Small Open OECD and Transition Economies: Comparing Apples with Oranges?, February 2007

1929 Aleksander Berentsen and Cyril Monnet, Monetary Policy in a Channel System, February 2007

1930 Wolfgang Ochel, The Free Movement of Inactive Citizens in the EU - A Challenge for the European Welfare State?, February 2007

1931 James K. Hammitt and Nicolas Treich, Statistical vs. Identified Lives in Benefit-Cost Analysis, February 2007

1932 Wilhelm Kohler, The Bazaar Effect, Unbundling of Comparative Advantage, and Migration, February 2007

1933 Karsten Staehr, Fiscal Policies and Business Cycles in an Enlarged Euro Area, February 2007

1934 Michele Bernasconi and Paola Profeta, Redistribution or Education? The Political Economy of the Social Race, March 2007

1935 Axel Dreher, Martin Gassebner and Lars-H. R. Siemers, Does Terror Threaten Human Rights? Evidence from Panel Data, March 2007

1936 Naércio Aquino Menezes Filho and Marc-Andreas Muendler, Labor Reallocation in Response to Trade Reform, March 2007

1937 Gebhard Flaig and Timo Wollmershaeuser, Does the Euro-zone Diverge? A Stress Indicator for Analyzing Trends and Cycles in Real GDP and Inflation, March 2007

1938 Michael Funke and Michael Paetz, Environmental Policy Under Model Uncertainty: A Robust Optimal Control Approach, March 2007

1939 Byeongchan Seong, Sung K. Ahn and Peter A. Zadrozny, Cointegration Analysis with Mixed-Frequency Data, March 2007

1940 Monika Bütler and Michel André Maréchal, Framing Effects in Political Decision Making: Evidence from a Natural Voting Experiment, March 2007

1941 Giacomo Corneo and Olivier Jeanne, A Theory of Tolerance, March 2007

1942 Qing Hong and Michael Smart, In Praise of Tax Havens: International Tax Planning and Foreign Direct Investment, March 2007 